\title{
Aotearoa New Zealand's New National History Curriculum and Histories of Mourning
}

\author{
Avril Bell $^{1}$ iD . Elizabeth Russell ${ }^{1}$
}

Received: 13 June 2021 / Accepted: 13 November 2021 / Published online: 24 November 2021

(c) The Author(s) 2021

\begin{abstract}
From 2022, New Zealand schools are teaching a new compulsory history curriculum that aims to teach diverse New Zealand histories, while foregrounding the centrality of Māori histories and the impacts of colonisation. The new curriculum will upend a long history of 'forgetting' the nation's contentious and conflictual past, and in particular the nineteenth century 'wars for New Zealand' (O'Malley, 2016) that secured settler hegemony over the nation-state. In this paper, we focus on the roles of remembering and forgetting in the narration of national histories to explore what might be a productive orientation to take to this contentious and unsettling past. We argue that the new history curriculum inaugurates a new phase of narrating the nation, replacing earlier phases of monocultural and bicultural nationhood that depended on this past being 'forgotten'. And we argue for the productive value of a histories of critical mourning approach to remembering this founding violence.
\end{abstract}

Keywords Difficult histories · Curriculum $\cdot$ Histories of mourning $\cdot$ Remembering and forgetting $\cdot$ Narrating the nation

It's a good time to reflect on [Thomas] King's idea of stories as 'wondrous' and also 'dangerous', to connect with the ways that the stories, the histories we tell shape us, and shape how we understand and relate to each other (Aroha Harris,

2019).

Like it is the living who really need history, so they it is who really make it (Geoff Park, 1999).

\section{Introduction}

In 2015, a petition was presented to Parliament by two Ōtorohanga College students, Leah Bell and Waimarama Anderson. The petition called for a day of commemoration for the New Zealand Wars, and for New Zealand history to be taught

Avril Bell

a.bell@auckland.ac.nz

1 University of Auckland, Sociology, Auckland, New Zealand 
in secondary schools. A year earlier Bell and Anderson had been on a school trip to Rangiaowhia, where kaumātua told their ancestors' stories about imperial and colonial soldiers attacking their undefended village in 1864. Amongst the atrocities committed, women, children, and elders were burnt alive in their houses and the community church (O'Malley \& Kidman, 2018, p. 299). Shocked, saddened, and disturbed that many teenagers are not exposed to such knowledge, Bell and Anderson's subsequent campaign was fuelled by a desire for New Zealanders to 'develop historical consciousness' and 'move beyond their harmful ignorance of the country's history' (Bell, 2020). Bell (2020) asserts that 'however difficult and uncomfortable our histories, we must let our children learn'.

The petition was one factor that contributed to changes to the National Curriculum for Years 1 to 10 to be implemented from 2022. Whereas schools can currently decide for themselves if New Zealand history is covered at all (Sheehan, 2017), these coming changes aim to 'reset a national framework so all learners and ākonga are aware of key aspects of New Zealand history and how they have influenced and shaped the nation' (Ardern \& Hipkins, 2019). Prime Minister Jacinda Ardern and Minister of Education Chris Hipkins (2019) declare that 'we can move forward together, stronger when we understand the many paths our ancestors walked to bring us to today'. These statements from Ardern and Hipkins indicate their awareness that memory is more than an individual faculty, and that it is as much about the future as the past. National histories are a social practice of remembering the past to make sense of the present and imagine a shared future (Connerton, 1989). Historical reconstruction is an essential part of collective, conscious efforts to reconstruct social relations (Connerton, 1989), and the memories we choose to keep and tell ourselves about 'New Zealand' are part of a broader political project to imagine national unity and solidarity. Indeed, some supporters of the new curriculum echo Ardern and Hipkins in the view that remembering historical struggles for land and sovereignty is crucial for reconciliation between Māori and Pākehā and for forging a renewed national identity (O’Malley \& Kidman, 2018, p. 301).

In contrast, previous versions of national identity have been constructed through significant social practices of forgetting. A common account of New Zealand history, widely rehearsed by leaders, educators, and the media, is that British colonisation was a fairly benign and consensual experience (Huygens, 2018; Stewart, 2018; Wynyard, 2017); 'Pākehā turned up, shook hands and hongied with tangata whenua', then 'bi-culturally blissed out for $150+$ years of paternalistic colonial destiny, farming sheep and doing hakas before rugby matches' (Botes, 2015). Indeed, for much of last century a strong thread of 'forgetting' supported Pākehā national hegemony and fuelled the boasting of Pākehā New Zealanders about their nation having the most harmonious race relations in the world. In 2008, then Prime Minister John Key demonstrated the persistence of this discourse by claiming that 'we're not a country that's come about as a result of civil war or where there's been a lot of fighting internally' (Botes, 2015).

In 2014, Key reasserted on Te Hiku Radio that New Zealand was peacefully settled, adding that British settlers brought skills and capital that Māori welcomed (Wynyard, 2017, p. 15). There is evidence to support this latter point during the 
early colonial period when Māori still held the balance of power and the sharing of trade and technology seemed mutually beneficial. In the 1840s and early 1850 s, Waikato Māori were considered the 'life blood' of Auckland's economy, and even relocated some of their people to the town's outskirts to protect settlers from other iwi (O’Malley, 2016, p. 9; also see Hargreaves, 1961; Petrie, 2006; Monin, 2009). However, once the pressure from settlers for land exceeded Māori willingness to sell, and Māori political initiatives such as the Kingitanga were deemed to block the extension of settler sovereignty, the colonial regime resorted to violence and invasion of Māori strongholds across the North Island to secure Pākehā political hegemony and dominance over the agricultural economy, shattering any aspirations to 'peaceful settlement'.

The contemporary narrative of 'peaceful settlement' points to the ongoing power of a politics of forgetting the violence and injustice of our past. Paul Connerton (2011) posits that not remembering can constitute identities and provide permanence and belonging for heterogeneous members of societies. To take an uncontentious example, over time as British identities became increasingly irrelevant for settler families, faraway ties were forgotten and local ones asserted, settlers ceased to be British and became New Zealanders. However, the resulting Pākehā-dominated national identity-making was a distinctly colonising process that violently suppressed difference and forcefully assimilated Māori into the singular Europeancentred nationality of 'New Zealander'. For the creation of this Pākehā-dominated nation and the replacement of 'Aotearoa' with 'New Zealand' to succeed, the founding violence perpetrated by settler colonisers, physical, cultural, and economic, had also to be 'forgotten' (Bell, 1996, p. 151; Turner, 1999). This practice of actively ignoring and avoiding the past is harmful because it allows the continuation of colonialism and Pākehā hegemony; Māori disadvantages can be seen simply as Māori problems, disconnected from Pākehā advantages, and Māori political claims can be cast as unreasonable and disruptive. Yet because settler colonisers and their descendants have gained power and privilege within a Pākehā-centred nation, remembering histories of migration and violent colonisation may result in deep discomfort, and even spark denial, for Pākehā. Such remembering involves nothing short of a disruption to their sense of themselves and their community as New Zealanders.

Thus, the unifying potential of 'unforgetting', or remembering what has previously been forgotten, is not guaranteed. Vincent O’Malley and Joanna Kidman's (2018) analysis of submissions made on the proposed curriculum changes includes examples of this disagreement regarding the remembering of 'difficult histories'. Submitters writing in support of the new curriculum envisaged a new national unity based on reconciliation and healing of the injustices faced by Māori in the past (O'Malley \& Kidman, 2018, p. 301). Some suggested that attention given to this hugely formative time in the nation's history would provide an important deepening of the national narrative (ibid) and in this way would strengthen national identity. One Pākehā submitter, Susan Healy, argued specifically that Pākehā ties to the nation would be strengthened by deeper knowledge of colonial history. She suggested that learning about Māori relationships with the land 'will build our sense of relationship to the land, and increase our sense of pride and identity through that relationship' (in O’Malley \& Kidman, 2018, p. 301). 
In contrast, amongst submitters arguing against the petition for curriculum change, many expressed the discomfort and anxieties of the dominant group concerned to maintain the status quo, and their own positions of privilege. A number expressed a concern that remembering colonial violence would be divisive and that the proposed changes were being driven by 'separatists' (ibid, 302). Others linked the 'rewriting' of history more broadly with the work of the Waitangi Tribunal and Treaty settlement processes, suggesting that it was motivated purely by the 'greed' of Māori elites (ibid). There was concern also that, in focusing on New Zealand's colonial past instead of praising the country's progressive achievements and fostering feelings of security, innocence, and pride, challenges to the dominant national narrative may cause Pākehā students to feel bad about themselves and increase the likelihood of 'unrest' (ibid, 302). Resistance to and anxiety about the possibilities of a changing balance of power are evident in these lines of argument.

Thus, introducing a compulsory national curriculum addressing the violence of what were effectively civil wars, or wars 'for New Zealand' (O'Malley, 2016, emphasis added), comes with no guarantees that a new national unity will be forged that allows us to 'move forward together, stronger' as Ardern and Hipkins suggest and O'Malley (2018) argues for. The emotional discomforts and anxieties of de-centring Pākehā norms and narratives could inhibit the ability of, particularly Pākehā, students to receive and respond to revised histories in a constructive way. Hence the positive outcomes envisaged for the new curriculum will need to be worked at and will require careful pedagogical skills amongst the nation's teachers (see Harcourt, 2020; Sheehan \& Ball, 2020; Yukich, 2021). A national curriculum that honours 'the many paths our ancestors walked' will also need a particular orientation to the subject of societal history itself, one that facilitates new rememberings in ways that enable students to navigate the unsettling of the status quo involved and offer possibilities for a societal future.

In this paper, we explore arguments regarding remembering and forgetting in the narrating of national histories and Paul Connerton's concept of histories of mourning (outlined below). We also explore the arguments of New Zealand historians (Peter Gibbons, Giselle Byrnes, Nepia Mahuika) against the narration of national histories per se, and in favour of alternative, multiple and complex narratives about the/our past. From this foundation, we trace two periods of in the popular/public narration of New Zealand national history to date, highlighting the ways in which different mixes/forms of selective remembering and forgetting have ensured the establishment and continuity of Pākehā hegemony over the national narrative in each period, emphasising the legitimacy of settler colonialism and weakening assertions of Māori sovereignty. Māori history and presence have not been 'forgotten' in toto, but the history of Māori-Pākehā relations has been narrated in ways that have served to maintain Pākehā hegemony, first via a national history of assimilation and secondly, in response to ongoing challenges from Māori, a history of biculturalism which shifted, but has not dislodged, that hegemony. We argue that the second period of proliferating and bifurcating histories might be viewed as transitional, as one that points towards a third period as envisaged by the proponents of the new history curriculum and inspired by the critiques of national histories amongst academic historians. We characterise this period as one in which the nation is narrated as a 
question and sketch out the possibilities for a critical mourning approach as a productive orientation towards our difficult nineteenth century history.

\section{Remembering, Forgetting and Mourning in National Histories}

In his influential essay, Ernest Renan argues that nations are forged first and foremost as an act of will on the part of the citizenry. A nation, he argues, is the expression of a choice for unity rather than being based on any objective criteria that are often pointed to, such as common language or religion. A nation is fundamentally a matter of stories of a shared past and future, thus histories are central: 'To have common glories in the past and to have a common will in the present; to have performed great deeds together, to wish to perform still more-these are the essential conditions of being a people' (Renan, 1990 [1882], p. 19). This argument might imply that remembering division and violence between us in the past cannot be the basis of forging a national unity. Instead, as some submitters on the petition suggested, such memories are divisive. And, in fact, Renan (1990 [1882], p. 11) observes that 'the essence of a nation is that all individuals have many things in common and also that they have forgotten many things'. In particular, Renan argues for the usefulness of forgetting histories of war and violence between groups within the nation. ${ }^{1}$

For Paul Connerton (2011, p. 1), the kind of national history that Renan is concerned with is one example of a history of legitimation-a state-sponsored history that justifies the political and social order. Connerton argues that this is one of the main reasons why histories are written and that the practice of legitimation can be viewed positively or critically. Positively, histories of legitimation might be seen as a universal practice - all communities account for their existence and for their systems of law and governance via stories that justify and recount their becoming. Critically, all such histories of legitimation involve exclusions (Connerton, 2011: 1-2). Connerton (2011) also distinguishes between seven types of forgetting, the most pertinent for our argument being 'constitutive forgetting', forgetting in the interests of constructing or founding a new identity_forgetting as gain, rather than loss:

the gain that accrues to those who know how to discard memories that serve no practicable purpose in the management of one's current identity and ongoing purposes. Forgetting then becomes part of the process by which newly shared memories are constructed because a new set of memories are frequently accompanied by a set of tacitly shared silences. Many small acts of forgetting which these silences enable over time are not random but patterned (Connerton, 2011, p. 37).

This is the forgetting that has allowed the descendants of British colonising migrants to become 'New Zealanders' and, in fact, to 'forget' in important ways that

\footnotetext{
1 See Benedict Anderson (2006, pp. 199-203) on the ways in which Renan's argument depends on the paradoxical assumption that the nation exists already, in the sense that there must already be an existing community engaged in a mix of practices of 'fraternal' remembering and forgetting.
} 
they/we are of migrant origin at all. To 'remember' our families' migration would be to remember also that this is first a Māori country and to raise the question of why we/Pākehā, as migrants, have not assimilated to Māori society but have demanded the reverse. 'Settlement as forgetting', in Stephen Turner's (1999) terms, involves a double forgetting - forgetting of the trauma and loss that accompanies migration and forgetting of the violence against Māori by which settlement was secured.

All of this points to the value of forgetting in forging national unity, albeit at the cost of acknowledgement of historical violence and injustice against Māori, as well as the cost to understanding who Pākehā are, as the resulting truncated, 'picketed history' cuts them/us off from the foundations and processes of their/our situation (Turner, 1999, p. 32). What then, we might ask, is to be gained by a shift to remembering the violence and injustice of the past? A central purpose of remembering past injustices in the history of Aotearoa New Zealand is to face up to the ways in which the present inequalities experienced by Māori are the continuation of that past. As envisaged by the government, a new national unity is to be forged from remembering that past and weaving it into a new national narrative.

However, others warn against the politics of any desire to narrate national unity. In 2002 and 2003, New Zealand historian, Peter Gibbons wrote two influential papers in which he argued against a focus on national identity in the writing of New Zealand history. On the one hand (2002), in a clear critique of settler histories of legitimation, Gibbons argues that narrations of New Zealand nationhood are the continuation of colonisation, a form of 'cultural colonisation'. On the other (2003), he calls for the writing of macro and micro-histories that cut across the nation-centred focus, locating New Zealand within the world and the world within New Zealand. Subsequently, as editor of The New Oxford History of New Zealand in 2009, Giselle Byrnes (2009, p. 1) picked up this critique of national histories and aimed to produce a collection that 'writes against' the quest for national identity and for national uniqueness/exceptionality. The New Oxford History collection aimed instead to collate diverse and complex histories of New Zealand communities and localities, eschewing any overarching narrative or end state of unity. And more recently, Nepia Mahuika has mounted a similar critique of narratives of national unity when he argues that New Zealand histories that 'pretend to assert the essential narrative of "here"" are 'playing native' (2015, p. 25 nt6), in other words, appropriating indigeneity.

That said, 'New Zealand' is the 'container' that unites the histories included in the New Oxford History and will also be the container for the new history curriculum. Attention to macro and micro historical themes can offer new understandings of the connections and similarities between 'here' and 'there' and the diversity of experience within New Zealand, but are supplementary rather than complete replacements for the national frame. Gibbons, Byrnes and Mahuika all call for multiple histories of 'here'complex, layered, particular, interwoven. The challenge still remains to consider how nineteenth century colonial violence and injustice is to be remembered within and through these complex stories, how the legacy of that violence is to be narrated in accounts of the present, how 'New Zealand' itself might be reconceived in the process and how these new histories might contribute to visions of a societal future. 
In addition to his argument that forgetting intra-national violence is necessary to national unity, Renan (1990 [1882], p. 19), argues that 'suffering in common unifies more than joy does [and that] where national memories are concerned, griefs are of more value than triumphs, for they impose duties, and require a common effort'. Relatedly, Anderson (2006, p. 144) points to the 'moral grandeur' of dying for one's country in war. This argument makes sense, for example, of why memorialising the defeat at Gallipoli on Anzac Day has been such a powerful founding national memory for both Australia and New Zealand. But the griefs and losses remembered on Anzac Day are those experienced at the hands of external enemies, not those experienced at the hands of each other.

However, we are struck also by Connerton's (2011, p. 4) observation that 'the verb "to care" [...] used to have a meaning now declared obsolete, namely, "to mourn", so caring was once connected to memory through the idea of mourning'. The link between caring and mourning suggests that our affective commitments to/ care for the nation - both as idea and community - might include forms of mourning for the sufferings and losses in the histories of all the communities that make up the nation. We are all familiar with mourning following the loss of life as an expression of care for the lost family member or friend. But how can this translate into the work of historical remembering as national mourning for the past? Connerton (2011, p. 17) argues that we don't have ready-made rituals of mourning to cope with historical societal traumas, but that histories of mourning can become such means. He argues there is a 'sea-change in historiography' towards such histories, as evidenced in the rise of the 'culture of public apology' (ibid), apparent locally in the apologies from the Crown to iwi and hapu in Treaty settlements, in then Prime Minister Helen Clark's apologies to Samoa and to Chinese New Zealanders in 2002, and in Jacinda Ardern's 2021 apology to Pacific communities for the racist Dawn Raids of the 1970s. Further, Connerton suggests that histories of legitimation and mourning are not entirely separable, but are often intertwined (2011, pp. 27-30). In the remainder of this paper, we provide an overview of the shifting mix of remembering and forgetting in two historical phases of popular/public national history-making, before returning to the possibilities of histories of mourning as a productive approach to the nineteenth century civil wars 'for New Zealand'.

\section{Narrating New Zealand}

\section{Narrating the Monocultural Nation}

The early twentieth century period also saw an embryonic 'New Zealand' identity begin to form amongst the settlers, albeit one firmly nested within a patriotic allegiance to and identification with the British Empire. With Māori no longer considered a threat, the Pākehā state invested itself in national story-telling, or a 'cultural colonisation' (Gibbons, 2002) that positioned Māori and the history of colonial violence in ways that supported a monocultural Pākehā hegemony. In literary culture, this was the era of 'Māoriland literature', as Jane Stafford and Mark Williams (2006, p. 11) argue, a literature that 'denies what it seems to state: that New Zealand is a 
land belonging properly to Māori'. Rather, Māori were positioned as the nation's past to provide a 'mythologised or decorative presence' (ibid, 20) in the Pākehā nation.

Selective remembering and forgetting (on the part of the settler community) of nineteenth century state-directed invasions of Māori communities was central to the construction of this embryonic national identity. In her research on the involvement and effects of the wars on the Māori and Pākehā children of the time, Jeanine Graham (2002, p. 217) argues that the post-war period established attitudes on both sides that were resistant to subsequent change. While many Māori children of the era would have been raised on the memories of the violence and injustice that played out in inter-tribal relations as well as a broad mistrust of the settler society, for Pākehā children, in contrast, their community's desire to forget and put this problematic past behind them quickly established a widespread ignorance of the significance of these conflicts (Graham, 2002, pp. 223-224). By the early twentieth century the reframing of the history of conflict into a tale of unity was evident. Even though warfare had continued in the North Island until 1872, '50 years of peace' were celebrated in 1914 on the fiftieth anniversary of the 1864 battle of Ōākau (O'Malley, 2016: 18). The New Zealand Herald at the time explained the significance of this battle as 'the final acceptance of the British mana by a heroic and warlike native people' (cited in O'Malley, 2016, p. 17). By the time of the 1925 film Rewi's Last Stand, a mythologised rendition of Ōrākau that became part of the School Film Library catalogue, proclaimed that 'the slowly blending races of white men and brown live in peace and equality as one people... the New Zealanders' (O'Malley, 2016, p. 23).

At the same time, New Zealand history was taught in schools, albeit as a regional subset of a British nationality and celebration of empire. In Our Nation's Story (Britain being the nation), a popular set of history texts in the early twentieth century, the violence of the nineteenth century was not forgotten so much as narratively resolved in tales of mutual admiration for the valour of each side forged through these conflicts. This violent past was represented as settled and as having led to equality and friendship between the 'races'. The culpability of the Pākehā side as instigators of conflict, and the material, psychic and cultural costs for Māori of their subjection were crucially 'forgotten'. In the Standard V (now Year 7) volume, the nineteenth century wars were described as 'a fire in the fern' (Our Nation's Story, n.d. p. 26), a natural disaster with no human agent to blame. And in the Standard VI (Year 8) volume, the recounting of the wars ends: 'Today [Māori and Pākehā] live side by side as friends and fellow-citizens, loving the land whose broad and fertile acres support them both' (Our Nation's Story, n.d. p. 50), completely erasing the seizure of Māori lands that followed the wars and the relegation of Māori communities to marginal lands and subsistence livelihoods. This narration continued well into the twentieth century, with Our Country's Story (1963), the successor to Our Nation's Story, stating there was 'no country in the world where two races of different colour live together with more goodwill towards each other' (cited in O'Malley \& Kidman, 2018, p. 305).

Overall, 'New Zealanders' in this period, in stark contrast to the realities of colonial atrocities such as at Rangiaowhia, were encouraged to believe that the courage and respect demonstrated by both sides, and their 'honourable adherence to the 
outcome of a fair fight' (Nairn \& McCreanor, 1991, p. 248), laid the foundations for relations of friendship between Māori and Pākehā (O’Malley \& Kidman, 2018, p. 305). In Aroha Harris's (2019) terms, this narration of national unity 'gave us the myth of the benevolent coloniser and the bold but ultimately defeated and eventually assimilated Indigenous people'. Stories of the New Zealand Wars were thereby funnelled into a discourse that legitimated Pākehā domination, framing settlers as moral and noble and the rightful inheritors of Māori lands and authority. As Giselle Byrnes (2009, p. 5) describes it, Māori 'appeared as stage hands or curtain-raisers to the main theatrical performance of European arrival and settlement'.

\section{Narrating Bicultural Aotearoa New Zealand Through Bifurcating Histories}

Although selective remembering and forgetting of the New Zealand Wars supported the new national narrative of peace and unity, iwi and hapu nationwide continued to remember nineteenth century injustices and sought to have them remedied throughout the twentieth century (for example via the Sim Commission of 1926-1927). Ultimately, Māori activism of the 1960s and 1970s, such as the Land March of 1975 and the annual protests at Waitangi, finally brought darker memories about New Zealand's 'settlement' into wider public consciousness. Matiu Rata, as the MP for Northern Māori at the time, was able to shepherd the establishment of the Waitangi Tribunal through the Labour government. Initially only able to hear claims relating to contemporary issues, under the next Labour government of 1984-1990 the powers of the Tribunal were extended to encompass historical conflicts and Treaty breaches. Thus iwi and hapū perspectives and experiences of nineteenth century conflicts were again brought to the attention of government. Since that time, successive governments have pursued policies of Treaty settlement that have involved new narrations of nineteenth century history. For example, the 1995 Crown apology to Waikato Tainui officially abandoned accounts of the Waikato War beginning with 'native aggression towards well-intentioned settlers' (Hanly, quoted in Stewart, 2018, p. 76) and conceded that the government had unfairly labelled Waikato as 'rebels' and unjustly invaded their territory (O'Malley, 2016, p. 11).

During this same period, courses in New Zealand history began to appear in the universities, spearheaded by the work of Keith Sinclair and Bill Oliver. Byrnes (2009, p. 6) argues that these two 'legitimised' New Zealand history as a topic 'worthy of scholarly inquiry'. Thus from the 1960s onwards, and also propelled by the rise of feminism and civil rights movements, local and social histories proliferated in the universities and in scholarly — and popular-texts.

Alongside these proliferating Treaty and academic histories however, it is arguable that the popular imaginary of the national narrative has not moved on in the same ways - as evident in the continuation of the 'peaceful settlement' discourse noted earlier. Tribunal histories have been largely a matter between the Crown and the iwi concerned, leaving the general Pākehā population uninformed about historical grievances and the reasons behind Māori receiving redress through Treaty settlements (Bell, 2006, p. 259). This public disconnection from 'unforgotten' histories 
means that the ongoing impacts of colonisation remain understood as Māori, not Pākehā, problems.

The development of a national narrative of biculturalism since the 1970s has also, seemingly paradoxically, been largely inimical to any general reconsideration of the nation's colonial history of violence. While this period has been important in highlighting the resilience and distinctiveness of Māori culture despite widespread assimilationist practices, it has tended to assert the 'equality' and 'separateness' of Māori and Pākehā cultures and communities (Bell, 2006, p. 258). Museums and heritage sites, for example, have presented the two remembered histories independently of each other, avoiding explicit indications of overlap (Huygens, 2018, p. 265). An example is the bifurcation between the Māori and 'Passports' exhibitions in the initial organisation of the national museum, Te Papa Tongarewa, from its opening in 1998. This bifurcation of Māori and Pākehā histories facilitated the ongoing 'forgetting' of colonial battles and their aftermath (Bell, 2006, p. 258), constituting a biculturalism in which Māori and Pākehā histories are narrated separately, maintaining the colonial 'non-encounter' (Veracini, 2011, p. 2).

In recent times however, there is an increasing turn towards public 'remembering' of the conflicts of the nineteenth century. A number of museum exhibitions have been mounted centring on the nineteenth century wars, including the Taranaki War exhibition at Puke Ariki in New Plymouth in 2010, marking the 150th anniversary of the outbreak of hostilities in the region, and the Auckland Museum's 2020 exhibition, Stand in Peace: Exploring the New Zealand Wars. The new history curriculum is a significant marker of this turn, given its nationwide reach and the impact it will have on generations of New Zealand school children from 2022. The new curriculum will also spur the development of a proliferation of new resources, an impetus already evident in Radio New Zealand's The Aotearoa History Show (https://www.youtube.com/channel/UCGyiIcb-T6kQ_KNpfG6ehVA) and New Zealand Wars podcast and video series (https://www.rnz.co.nz/nzwars). How these new rememberings will respond to the challenges laid down by historians such as Gibbons, Byrne and Mahuika, and navigate the 'unsettling' and emotional responses of teachers and students to maximise the visions of the developers and policy makers remains to be seen. In the final section of this paper, we draw on and expand on the possibilities of histories of mourning as canvassed above to suggest a number of guiding orientations to the narrating of 'New Zealand' histories.

\section{Narrating 'New Zealand' as a Question}

The new history curriculum is a profoundly significant development that will expose all young New Zealanders to New Zealand histories. There are many notable features of the current draft curriculum that suggest it has been explicitly designed with the critiques of previous versions of narrating the nation in mind. The curriculum name, 'Aotearoa New Zealand Histories', points to the incorporation of multiple histories, rather than a singular national narrative to be told. And the three big ideas around which the curriculum is organised are clearly aimed to avoid past tendencies of Pākehā-centrism and uncritical celebration of national unity: 
- Māori history is the foundational and continuous history of Aotearoa New Zealand.

- Colonisation and its consequences have been central to our history for the past two hundred years and continue to influence all aspects of New Zealand society.

- The course of Aotearoa New Zealand's history has been shaped by the exercise and effects of power. (Ministry of Education, 2021, p. 2)

Explicit teaching of the nineteenth century violence that tore apart the society of the time to enforce Pākehā hegemony is reserved for the final Years 9 and 10 classes (Ministry of Education, 2021, p. 5). The challenge will be how to teach this difficult history while resisting the impulse towards tidy resolutions that mirror the colonial narratives of earlier eras, and in a way that can overcome the emotional resistances and disavowals that many students (and teachers themselves), particularly Pākehā as the inheritors of historical colonial privilege, may struggle with. Inclusion of these founding violences of the nineteenth century in the new history curriculum was at the heart of the student petition that catalysed curriculum change and is at the heart of our concerns in this paper. In another paper, Elizabeth Russell (2022, forthcoming) addresses the issue of the emotional responses of, particularly Pākehā, students to learning this difficult history, arguing that teachers can productively work with, rather than try to sidestep, the discomforting emotions of students as they 'remember' this troubling history, and pointing to ways in which emotions can be productive and transformative rather than blocks to new learning. Here, we want to conclude by exploring further the possibilities of mourning as a powerful and productive orientation to our histories that can support the transformative new understandings the curriculum developers hope for.

To mourn is to grieve for loss - the loss of life, property and way of life that the violences of colonisation meant for Māori, the loss of origin/roots and of innocence for Pākehā, the loss of alternative possibilities evident in some of the early contacts and agreements in our national story. But mourning has its risks. Mourning can be melancholic (Crewe, 2017) or nostalgic (Stow, 2017), mourning the loss of a past hegemony or for 'the restoration of an imagined past' (Stow, 2017, p. 150, cited in Pool, 2019, p. 431). Mourning as caring (for our ancestors, for each other in the present, and for the future), in Connerton's terms, cannot be any of these things. Rather, we follow Stephen Turner's (1999, p. 23) argument, directed at Pākehā in particular, that 'there is a need for national mourning, to grieve for the loss entailed in [colonial] settlement in order to embrace the difference of place'. This would be a mourning that involves facing the past in its complexity rather than tidying it up.

Simon Stow (2017, pp. 61-62, cited in Pool, 2019, p. 430), writing about US histories and mourning, calls for a 'tragic public mourning [...] predicated on a worldview that is pluralistic in outlook, critical and self-consciously political' and 'seeks to generate ambivalence in its audience'. Similarly, Olga Taxidou (2004, p. 98) argues for mourning in which 'loss is transformed into knowledge and critique' and for mourning that 'becomes the site where the subject-in-the-making is confronted with the polis-in-the-making' (Taxidou, 2004, p. 187). These visions of critical mourning suggest opening up the past as a means to inquire into the present and the future, to celebrate the achievements and survivals and to grieve the shortcomings 
and mistakes of history as a means to reflect on how we might move forward differently. They suggest also interrogating the nation (and nation-state) as a question and a process-in-the-making, rather than a settled achievement.

Critical mourning of necessity involves a confrontation with the differences woven through the nation's history and present. In a powerful sense, a critical mourning of our past would enable Pākehā to finally 'arrive' here, by overcoming their/our 'denial of the experience of contact' (Turner, 1999, p. 35). It would involve embracing the difference of Māori experience and of Aotearoa as a Māori country. Here we are reminded of Lorenzo Veracini's (2011, p. 2) observation that settler colonialism is characterised as a 'non-encounter', in that the settler refuses and denies their relationship and interdependence with indigenous communities. The new national history curriculum, in contrast, centring Māori history and frontfooting Māori experience of place, is an opportunity for encounter, and for Pākehā (and all non-Māori) to finally 'arrive'.

Critical histories of mourning involve viewing the past as complex, without clear cut 'goodies and baddies', but acknowledging the complex intertwinements of Te Ao Māori and Te Ao Pākehā that have been at times mutually enriching as well as destructive and dominating. Such recognition of the complexity of our communities and their historical relations must be held in tension with the question of the (il) legitimacy of Pākehā hegemony. Critical histories of mourning are not tidy, but it is this very complexity that can make history a compelling and lively subject for students. We need histories, Aroha Harris (2019) argues, that can 'comfortably [and at times, uncomfortably] hold differences in tension with each other'.

Dame Anne Salmond (in Warne, 2020, emphases added; also see Te Punga Somerville, 2018) has called for a 'whakapapa approach to history', as an approach that can hold diversity and tensions together:

If we [...] gave our children a view of the world that starts with the beginning of the cosmos and celebrates the long period that these islands were inhabited by birds and reptiles and trees and so on, and gave them a sense of kinship with that, and then let them see their own ancestors arriving in successive migrations, you bind them into that story.

And if our ancestors - any of them-did dreadful things, you don't censor it, you don't try to make it pretty, you tell the story. The kaumätua I know do that. They don't varnish the narrative. Then you're left to make up your mind. It's not preaching. You don't tell people what moral position to take. You tell the story.

And the way it's told is not on the basis of binary hatred, but rather that this is what happened. The heartbreak of that. We're still living with that legacy. That history hasn't emerged and hasn't been dealt with. [...] I think we're small enough and interconnected enough to do that here and not put ourselves into opposing camps and throw rocks at each other, and think that's a good way to run our country.

In this interview, Salmond also emphasizes that whakapapa are place-based and stresses the importance of local histories and local expertise being centred in the telling of history. We welcome this local emphasis in the draft curriculum for the 
rich possibilities it offers for the teaching of diverse and intricately entwined histories and for the way it resonates with the scholarship on the importance of placebased learning. Local histories are powerful ways to bring history to life for students. As Rachel Buchanan (2009, p. 264) has noted:

The big picture of colonisation is important; it needs to be examined, acknowledged and rectified. But zoom in and this reality blurs, dissolves, fractures and explodes. Spin the lens to close up on any corner of your family, your neighbourhood, your city, your nation, and a different picture emerges, one that is more complex, one that can not deny "the experience of contact", one in which forgetting is replaced by a rich, complicated and binding experience of entanglement. A more ethical future starts with a more ethical past, the sort that might be found in intimate histories, in crooked little family portraits.

To teach a critical history of mourning, teachers do not need to have all the answers or the end of the story, but will need to have the questions and an ability to hold those questions open and to encourage openness - and care-in their students. If a critical mourning is to be the basis of a new unity, it must be a unity built on diversity and disagreement, and a willingness to stay in relation with each other. This fits with Renan's argument that the nation is a 'daily plebiscite', a daily commitment to each other and the community-in-process. And as Salmond says, in a whakapapa view 'it's what you give, not what you hold on to, that makes you wealthy. And being in a state where your relationships are in some form of balance'.

\section{Conclusion}

The new history curriculum is an exciting-and challenging-development. It carries with it the weight of great expectations that it will instill a new historical consciousness in future generations and inform a revised sense of who 'we', New Zealanders, are and new imaginings of our national future. To even partially meet these aims will require careful thought about curriculum content and pedagogical strategies on the part of the nation's teachers (and significantly, most of these will not be history specialists). The histories of the nineteenth century 'wars for New Zealand' will be a particularly challenging component for Year 9 and 10 teachers and students to grapple with. In this paper we have focused not on what should be taught, but on orientations to what is taught. Accounts of the nineteenth century wars are contentious and unsettling-and hugely important to any just accounting of our past and re-envisioning of our future. Our argument here has been for an embrace of this complexity and contention, rather than a shying away or glossing over. We argue also that an orientation of care and critical mourning can make contention both manageable and productive, maintaining and reinforcing awareness of our ties with each other and daily commitment to stay in relation.

Acknowledgements We would like to thank our reading group companions, Rosalynd Boxall, Miranda Donovan and Samantha Lupton for the shared conversations during 2020 that fed our thinking in developing this work. 
Open Access This article is licensed under a Creative Commons Attribution 4.0 International License, which permits use, sharing, adaptation, distribution and reproduction in any medium or format, as long as you give appropriate credit to the original author(s) and the source, provide a link to the Creative Commons licence, and indicate if changes were made. The images or other third party material in this article are included in the article's Creative Commons licence, unless indicated otherwise in a credit line to the material. If material is not included in the article's Creative Commons licence and your intended use is not permitted by statutory regulation or exceeds the permitted use, you will need to obtain permission directly from the copyright holder. To view a copy of this licence, visit http://creativecommons.org/licen ses/by/4.0/.

\section{References}

Anderson, B. (2006). Imagined communities: Reflections on the origins and spread of nationalism (rev). Verso.

Ardern, J. \& Hipkins, C. (2019). NZ history to be taught in all schools. Beehive.govt.nz. Retrieved from https://www.beehive.govt.nz/release/nz-history-be-taught-all-schools.

Bell, A. (1996). 'We're just New Zealanders': Pākehā identity politics. In P. Spoonley, G. Pearson, \& C. Macpherson (Eds.), Nga patai: Racism and ethnic relations in Aotearoa/New Zealand (pp. 144158). Dunmore Press.

Bell, A. (2006). Bifurcation or entanglement? Settler identity and biculturalism in Aotearoa New Zealand. Continuum, 20(2), 253-268.

Bell, L. (2020). History demands a personal reckoning. E-Tangata. Retrieved from https://e-tangata.co.nz/ reflections/history-demands-a-personal-reckoning/

Botes, C. (2015). A perspective. NZ on Screen. Retrieved from https://www.nzonscreen.com/title/thenew-zealand-wars-1998/series/background

Buchanan, R. (2009). The Parihaka album: Lest we forget. Huia Publishers.

Byrnes, G. (2009). Introduction: Reframing New Zealand history. In G. Byrnes (Ed.), The new Oxford history of New Zealand (pp. 1-18). Oxford University Press.

Crewe, J. (2017). Boer melancholia: Ingrid Winterbach's 'Niggie.' English in Africa, 44(1), 15-33.

Connerton, P. (1989). How societies remember. Cambridge University Press.

Connerton, P. (2011). The spirit of mourning: History, memory and the body. Cambridge University Press.

Gibbons, P. (2002). Cultural colonization and national identity. New Zealand Journal of History, 36(1), $5-17$.

Gibbons, P. (2003). The far side of the search for identity: Reconsidering New Zealand history. New Zealand Journal of History, 37(1), 38-49.

Graham, J. (2002). Children and the New Zealand Wars: An exploration. In J. Marten (Ed.), Children and War: A Historical Anthology (pp. 216-226). New York University Press.

Harcourt, M. (2020). Teaching and learning New Zealand's difficult history of colonisation in secondary school contexts (PhD thesis). Victoria University, Wellington.

Hargreaves, P. (1961). Māori flour mills of the Auckland Province: 1846-1860. The Journal of the Polynesian Society, 70(2), 227-232.

Harris, A. (2019). Teaching Māori history must not be simply a spray tan to brown up the past. The Spinoff. Retrieved September 14, 2019, from https://thespinoff.co.nz/atea/14-09-2019/new-zealandhistory-must-be-more-than-just-a-bunch-of-cute-facts/

Huygens, I. (2018). 'Head and heart' responses to Treaty education in Aotearoa New Zealand: Feeling the timeline of colonisation. In L. Smith, M. Wetherell, \& G. Campbell (Eds.), Emotion, affective practices, and the past in the present (pp. 265-280). Routledge.

Mahuika, N. (2015). New Zealand history is Māori history: Tikanga as the ethical foundation of historical scholarship in Aotearoa New Zealand. New Zealand Journal of History, 49(1), 5-30.

Ministry of Education. (2021). Aotearoa New Zealand's Histories in the New Zealand Curriculum: Draft for consultation. New Zealand Government. Retrieved May 13, 2020, from https:/www.education. govt.nz/assets/Documents/Aotearoa-NZ-histories/MOE-Aotearoa-NZ-Histories-A3-FINAL-020-1. pdf 
Monin, P. (2009). Māori economies and colonial capitalism. In G. Byrnes (Ed.), The new Oxford history of New Zealand (pp. 125-146). Oxford University Press.

Nairn, R., \& McCreanor, T. (1991). Race talk and common sense: Patterns of Pākehā discourse on Māori/ Pākehā relations in New Zealand. Journal of Language and Social Psychology, 10(4), 245-262.

O'Malley, V. (2016). The great war for New Zealand: Waikato 1800-2000. Bridget Williams Books.

O'Malley, V. (2018). A mature nation owns its history-the good and the bad. Stuff. Retrieved from https:// www.stuff.co.nz/national/106043529/a-mature-nation-owns-its-history--the-good-and-the-bad

O'Malley, V., \& Kidman, J. (2018). Settler colonial history, commemoration and white backlash: Remembering the New Zealand Wars. Settler Colonial Studies, 8(3), 298-313.

Our Nation's Story: A Course in British History. Standard V. (n.d.). Whitcombe \& Tombs Ltd.

Our Nation's Story: A Course in British History. Standard VI. (n.d.). Whitcombe \& Tombs Ltd.

Park, G. (1999). Going between goddesses. In K. Neumann, N. Thomas, \& H. Ericksen (Eds.), Quicksands: Foundational histories in Australia and Aotearoa New Zealand (pp. 176-197). University of New South Wales Press.

Petrie, H. (2006). Chiefs of industry: Māori tribal enterprise in early colonial New Zealand. Auckland University Press.

Pool, H. (2019). Book Review: American mourning: Tragedy, democracy, resilience, by Simon Stow. Political Theory, 47(3), 429-434.

Renan, E. (1990)[1882]. What is a nation? In H. Bhabha (Ed.) Nation and Narration, (pp. 8-22). Routledge

Russell, E. (2022, forthcoming). Crossing the minefield of anxiety, guilt, and shame: Working with and through Pākehā emotional discomfort in Aotearoa New Zealand histories education. New Zealand Journal of Educational Studies.

Sheehan, M. (2017). A matter of choice: Controversial histories, citizenship, and the challenge of a highautonomy curriculum. Curriculum Matters, 13, 103-114.

Sheehan, M., \& Ball, G. (2020). Teaching and learning New Zealand's difficult histories. New Zealand Journal of History, 54(1), 51-68.

Stafford, J., \& Williams, M. (2006). Māoriland: New Zealand Literature 1872-1914. Victoria University Press.

Stewart, G. T. (2018). Accurate histories, critical curriculum: A conversation with Tamsin Hanly. Curriculum Matters, 14, 69-86.

Stow, S. (2017). American mourning: Tragedy, democracy, resilience. Cambridge University Press.

Taxidou, O. (2004). Tragedy, modernity and mourning. Edinburgh University Press.

Te Punga Somerville, A. (2018). Inside us the unborn: Genealogies, futures, metaphors, and the opposite of zombies. In W. Anderson, M. Johnson, \& B. Brookes (Eds.), Pacific futures: Past and present (pp. 69-80). University of Hawai'i Press.

Turner, S. (1999). Settlement as forgetting. In K. Neumann, N. Thomas, \& H. Ericksen (Eds.), Quicksands: Foundational histories in Australia and Aotearoa New Zealand (pp. 20-38). University of New South Wales Press.

Veracini, L. (2011). Introducing settler colonial studies. Settler Colonial Studies, 1, 1-12.

Warne, K. (2020). A whakapapa approach to history. E-Tangata. Retrieved August 15, 2020, from https://e-tangata.co.nz/history/a-whakapapa-approach-to-history/

Wynyard, M. (2017). Plunder in the promised land: Māori land alienation and the genesis of capitalism in Aotearoa New Zealand. In A. Bell, V. Elizabeth, T. McIntosh, \& M. Wynyard (Eds.), A land of milk and honey? Making sense of Aotearoa New Zealand (pp. 15-22). Auckland University Press.

Yukich, R. (2021). Feeling responsible to Aotearoa New Zealand's past: Emotion at work in the stance of five Pākehā history teachers. New Zealand Journal of Educational Studies, 56, 181-199.

Publisher's Note Springer Nature remains neutral with regard to jurisdictional claims in published maps and institutional affiliations. 